\title{
MEDIA SOSIAL DAN PARTISIPASI POLITIK MILENIAL RIAU
}

\author{
Fitria Utami \\ Universitas Abdurrab \\ fitriaami29@gmail.com
}

\begin{abstract}
Abstrak
Penelitian ini bertujuan untuk melakukan pengujian tentang pengaruh media sosial terhadap partisipasi politik milenial di Riau. Media sosial saat ini merupakan sarana yang banyak digunakan oleh masyarakat dalam aktifitas kehidupan mereka sehari-hari terutama generasi milenial. Generasi milenial adalah sebuah istilah yang populer menggantikan istilah generasi $Y$ dimana sekelompok orang yang lahir setel ah generasi $X$, yaitu orang yang lahir pada kisaran tahun 1980-2000an. Generasi Y dikenal dengan sebutan millenial. Partisipasi politik umumnya dilihat dari keterlibatan masyarakat dalam memberikan hak pilih mereka dalam pemilu. Partisipasi politik tidak dibahas dalam cakupan yang lebih luas seperti kritisi kebijakan, pengujian petisi, dan demonstrasi. Penelitian ini berupaya untuk menjembatani gap tersebut yaitu mengkaji partisipasi politik pada spektrum yang lebih luas tersebut, terutama bagaimana pengaruh media sosial terhadap partisipasi politik milenial di Riau. Metode yang digunakan adalah kuantitatif. Pengumpulan data dilakukan melalui survei dengan menyebarkan kuesioner pada 204 responden. Teknik analisa data yang digunakan adalah analisis regresi linear sederhana. Hasil penelitian menunjukan ada pengaruh media sosial terhadap partisipasi politik milenial di Riau sebesar 0,205 (20,5\%).
\end{abstract}

Kata kunci:

generasi milenial, media sosial, partisipasi politik, Riau.

\begin{abstract}
This study is to test the influence of social media toward millennial's political participation in Riau. Social media is currently a tool widely used by people in their daily activities, especially millennial generation. Millennial is popular term that replaces the term generation $Y$ where a group of people born after generation $X$, that is, people born from 1980s to 2000s. Generation $Y$ is known as millennial. Political participation is generally seen from people's involvement in giving their voting rights in elections. It is not discussed in a broader scope such as policy criticism, petition, and demonstrations. This study tries to fill this gap, namely examining political participation on a broader spectrum, especially how the influence of social media on millennial political participation in Riau. The method used is quantitative. Data collection was carried out through a survey by distributing questionnaires to 204 respondents. The data analysis technique used is simple linear regression. The results showed there was correlationbetween social media and millennial political participation in Riau by 0.205 (20.5\%).
\end{abstract}

\section{Keywords:}

millennial, social media, political participation, Riau.

\section{PENDAHULUAN}

Di Indonesia media sosial telah menjadi trend dalam komunikasi sosial. Media sosial adalah sebuah media online, dengan para penggunanya bisa dengan mudah berpartisipasi, berbagi, dan menciptakan isi meliputi blog, jejaring sosial, wiki, forum dan dunia virtual yang merupakan bentuk media sosial yang paling umum digunakan oleh masyarakat di seluruh dunia (kompas.com, 2016). Media situs jejaring sosial tumbuh sangat cepat dan sangat populer, satu diantara yang paling populer adalah Facebook. Media sosial sebagai sebuah kelompok aplikasi berbasis internet yang 
membangun di atas dasar ideologi dan teknologi Web 2.0, dan yang memungkinkan penciptaan dan pertukaran user-generated content (Kaplan dan Haenlein 2010). Beberapa media sosial yang sedang berkembang saat ini yaitu instagram, twitter, line, facebook, youtube, dan lain-lain.

Era 1990-an dimana awal internet belum mendunia seperti sekarang, kehadiran internet menjadi sebuah karya besar dalam teknologi informasi. Hampir semua yang dahulunya dilakukan dengan manual, sekarang sudah bisa dikerjakan dengan bantuan internet. Masyarakat sudah "terhipnotis" sedemikian rupa sehingga internet telah menjelma menjadi salah satu kebutuhan primer. Hal tersebut tidaklah salah karena memang demikian adanya bahwa teknologi semakin mempermudah kehidupan manusia. Kehadiran media sosial telah membawa kepada perubahan ke arah partisipasi masyarakat secara online. Partisipasi masyarakat bukan hanya terjadi di dunia nyata tetapi juga di dunia maya (Ali \& Samsudin 2012 dalam Rumyeni 2017). Pesatnya pertumbuhan smartphone dan gadget juga menjadi faktor pendorong kejayaan media sosial. Perangkat tersebut menjadikan pengguna lebih mudah mengakses media sosial dimanapun dan kapanpun (Rumyeni 2017).. Sebagian besar pengguna media sosial adalah generasi milenial yang dilahirkan pada tahun akhir 1980-an atau awal 1990-an.

Generasi milenial atau sering disebut milenial saja adalah sebuah istilah yang populer menggantikan istilah generasi $Y$ di mana sekelompok orang yang lahir setelah generasi X, yaitu orang yang lahir pada kisaran tahun 1980-2000an. Generasi $Y$ dikenal dengan sebutan generasi millenial atau milenium. Ungkapan generasi Y mulai dipakai pada editorial koran besar Amerika Serikat pada Agustus 1993 (Putra 2016). Salah satu ciri yang melekat erat pada generasi ini adalah banyak menggunakan teknologi komunikasi instan seperti email, whatsapp, facebook, instagram, twitter dan berbagai media sosial lainnya. Sehingga generasi milenial adalah generasi yang menyukai teknologi dan mulai menyingkirkan cara konvensional dalam bertukar informasi.

Kaum milenial tumbuh dan berkembang pada saat media sosial sudah diperkenalkan sehingga generasi ini sangat mahir dalam teknologi. Milenial dapat dianggap sebagai inovator, karena mereka mencari, belajar dan bekerja di lingkungan inovasi yang sangat mengandalkan teknologi untuk melakukan perubahan di dalam berbagai aspek kehidupannya (Fatmawati 2010 dalam Walidah 2018). Nur Ainiyah (2018) mengungkapkan bahwa masa milenial adalah masa yang memiliki kepekaan begitu kuat terhadap hal-hal yang baru, sehingga milenial sangat begitu mudahnya beradaptasi terhadap sesuatu yang baru tersebut, apalagi media sosial adalah media yang begitu banyak menawarkan fitur-fitur yang mengasyikkan, sehingga millenial dengan sangat mudah tergiur oleh fitur-fitur yang mengasyikkan tersebut tanpa mempedulikan konten-konten yang terkandung dalam fitur-fitur tersebut positif atau negatif.

Media sosial bagi generasi milenial juga menjadi tempat dimana mereka mengekspresikan pandangan-pandangannya terhadap pemerintah sebagai bentuk partisipasi politik. Partisipasi politik secara umum ialah kegiatan warga negara yang dilakukan secara pribadi dan dimaksudkan untuk mempengaruhi keputusan yang dihasilkan pemerintah (Bisri n.d). Miriam Budiardjo (2008) menganggap partisipasi politik merupakan kegiatan individu atau kelompok untuk ikut secara aktif dalam kegiatan politik dengan cara secara langsung maupun tidak langsung dalam memberi pengaruh pengambilan keputusan. Partisipasi menjadi salah satu prinsip mendasar dari clean government. Di Indonesia, pelaksanaan partisipasi politik 
termuat dalam Undang-Undang Nomor 12 Tahun 2015 tentang Jaminan dan Perlindungan Negara terhadap Hak-Hak Sipil dan Politik Warga Negara, seperti menyampaikan pendapat hak berserikat, hak memilih dan dipilih, hak yang sama dihadapkan hukum dan pemerintahan serta hak mendapatkan keadilan. Adanya keputusan politik yang dibuat dan dilaksanakan oleh pemerintah menyangkut dan mempengaruhi kehidupan warga negara, maka warga negara berhak ikut serta menentukan isi keputusan politik (Murhaling 2014).

Pada kesempatan lain, partisipasi politik dalam pandangan Hutington dan Nelson seperti dikutip oleh Cholisin (2007: 151) adalah kegiatan warga negara yang bertindak sebagai pribadi-pribadi yang dimaksud untuk mempengaruhi pembuatan keputusan oleh pemerintah. Partisipasi politik didefinisikan sebagai aktivitas warga negara, termasuk di pelosok desa hingga perkotaan. Dalam hal ini, potensi kelompok milenial sangat besar, termasuk dalam urusan politik. Kaum milenial sangat signifikan berkontribusi pada arah politik masa depan. Dengan demikian, membangun partisipasi kelompok usia ini merupakan suatu hal yang sangat penting. Meskipun terdapat pesimisme dari segolongan orang akan berpartisipasi politik kelompok milenial ini. Ada dugaan bahwa kelompok yang berusia muda ini tidak tertarik dengan politik. Justru mereka perlu dirangkul dan didekati oleh pihak-pihak yang berkepentingan agar tumbuh kepedulian dan partisipasi politiknya. Partai politik, para kandidat dan tim sukses yang sedang berkontestasi perlu memahami dengan baik kelompok milenial ini. Ketepatan cara pendekatan dan komunikasi sangat menentukan keberhasilan dalam membangun partisipasi politik generasi milenial ini (Winarno 2018).

Riau merupakan salah satu provinsi yang ada di Indonesia yang jumlah generasi milenialnya terbilang banyak. Menurut survei Badan Pusat Statistik Provinsi Riau (2016), jumlah generasi milenial untuk kategori 19-34 tahun 2013 sebesar 2.248.922 jiwa. Berdasarkan data BPS tersebut, jumlah generasi milenial disetiap kabupaten/kota. Dari 12 kabupaten/kota di Riau, dapat dikatakan jumlah milenial terbilang banyak adalah Kota Pekanbaru sebesar 396.705 jiwa dan jumlah milenial yang paling sedikit adalah Kabuaten Meranti sebesar 65.680 jiwa.

Media sosial sangat berperan penting sebagai salah satu faktor yang dapat memberikan efek positif dalam peningkatan partisipasi politik di kalangan generasi milenial sebagai pemilih pemula. Namun partisipasi politik tidak semata-mata diukur berdasarkan pemberian suara pada saat pemilu. Pada dasarnya ada banyak bentuk partisipasi politik seperti: mengirim surat (pesan) kepada pejabat pemerintahan, ikut serta dalam aksi protes atau demonstrasi, menjadi anggota partai politik, menjadi anggota organisasi kemasyarakatan, mencalonkan diri untuk jabatan publik, memberikan sumbangan kepada partai atau politisi, hingga ikut serta dalam acara penggalangan dana (Kompas.com, 2018). Dengan demikian meskipun hanya pemula, tetapi partisipasi mereka ikut menentukan arah kebijakan Indonesia ke masa depan.

Pengaruh media sosial terhadap partisipasi politik menjadi salah satu indikator politik di Indonesia yang secara tidak langsung memiliki peran strategis dalam membentuk partisipasi politik. Berbagai macam informasi politik dapat diperoleh melalui media massa dan dapat mempengaruhi pandangan masyarakat dalam menentukan partisipasi politiknya. Berdasarkan latar belakang masalah di atas, maka penelitian ini ingin melihat adakah pengaruh media sosial terhadap tingkat partisipasi politik generasi milenial di Provinsi Riau. 


\section{KERANGKA ANALISIS}

Sebagai suatu alat untuk menyampaikan informasi, penilaian, atau gambaran umum tentang banyak hal, media mempunyai kemampuan untuk berperan sebagai institusi yang dapat membentuk opini publik (Muslimin 2019), antara lain karena media juga dapat berkembang menjadi kelompok penekan atas suatu ide atau gagasan, bahkan suatu kepentingan atau citra yang ia representasikan untuk diletakkan dalam konteks kehidupan yang lebih empiris (Miftakhul 2015). Media sosial menjadi arena yang memfasilitasi pengguna dalam berbagi ide, pikiran, informasi melalui jejaring dan komunitas virtual (Dollarhide 2019). Mc. Quail (2011) berpendapat bahwa fungsi utama media bagi masyarakat adalah sebagai sumber informasi (inovasi, adaptasi, dan kemajuan); korelasi (menjelaskan, menafsirkan, mengomentari makna peristiwa dan informasi, menunjang otoritas dan norma-norma yang mapan, mengkoordinasi beberapa kegiatan, membentuk kesepakatan); kesinambungan (mengekspresikan budaya dominan dan mengakui keberadaan kebudayaan. khusus (subculture) serta perkembangan budaya baru, meningkatkan dan melestarikan nilai-nilai); hiburan (menyediakan hiburan, pengalihan perhatian, dan sarana relaksasi, meredakan ketegangan sosial); mobilisasi (mengkampanyekan tujuan masyarakat dalam bidang politik, perang, pembangunan ekonomi, pekerjaan, dan kadang kala juga dalam bidang agama).

Partisipasi berarti mengambil peranan dalam aktivitas atau kegiatan politik negara (Suharno, 2004:102-103). Partisipasi politik merupakan ciri khas dari modernisasi politik. Adanya keputusan politik yang dibuat dan dilaksanakan oleh pemerintah menyangkut dan mempengaruhi kehidupan warga negara, maka warga negara berhak ikut serta menentukan isi keputusan politik. Partisipasi politik menurut Hutington dan Nelson yang dikutip oleh Cholisin (2007: 151) adalah kegiatan warga negara yang bertindak sebagai pribadi-pribadi yang dimaksud untuk mempengaruhi pembuatan keputusan oleh pemerintah. Selanjutnya menurut Budiardjo (2009:36) menyatakan bahwa partisipasi politik secara umum dapat didefinisikan sebagai kegiatan seseorang atau sekelompok orang untuk ikut secara aktif dalam kehidupan politik, yaitu dengan jalan memilih pemimpin negara dan langsung atau tidak langsung mempengaruhi kebijakan publik (public policy). Bentuk-bentuk partisipasi politik yang dikemukakan oleh Almond yang dikutip oleh Mas'oed (2011: 57-58) yang terbagai dalam dua bentuk yaitu partisipasi politik konvensional dan partisipasi politik non-konvensional. Adapun rincian bentuk partisipasi politik konvensional mencakup pemberian suara atau voting, diskusi politik, kegiatan kampanye, membentuk dan bergabung dalam kelompok kepentingan, komunikasi individual dengan pejabat politik atau administratif. Sementara partisipasi non-konvensional meliputi pengajuan petisi, berdemonstrasi, konfrontasi, mogok, tindakan kekerasan dalam bentuk harta dan benda, kekerasan fisik.

\section{METODE PENELITIAN}

Pendekatan dalam penelitian ini adalah pendekatan kuantitatif, karena penelitian ini disajikan dengan angka-angka. Hal ini sesuai dengan pendapat Arikunto (2006: 12) yang mengemukakan penelitian kuantitatif adalah pendekatan penelitian yang banyak dituntut menggunakan angka, mulai dari pengumpulan data, penafsiran terhadap data tersebut, serta penampilan hasilnya. Jenis penelitian ini adalah penelitian kuantitatif eksplanasi. Penelitian ini bermaksud untuk menjelaskan suatu generalisasi sampel terhadap populasinya atau menjelaskan pengaruh satu variabel 
Vol.3, No. 1 (Januari 2020)

doi: 10.36341/jdp.v3i1.1158

dengan variabel lainnya. Penelitian ini dilaksanakan di Provinsi Riau. Populasi dalam penelitian ini adalah seluruh milenial di Riau. Sampel penelitian sebesar 204 responden dengan tingkat kesalahannya $7 \%(0,07)$. Pengumpulan data dilakukan dengan survei melalui Google Form. Skala pengukuran yang digunakan oleh penulis adalah Skala Likert. Setiap pertanyaan atau pernyataan tersebut diungkapkan dengan: Sangat Tidak Setuju (1), Tidak Setuju (2), Ragu (3), Setuju (4), dan Sangat Setuju (5).

\section{Uji Validitas Instrumen Penelitian}

Uji validitas adalah sebuah pengujian yang ditujukan untuk menunjukkan sejauh mana suatu alat ukur atau instrumen penelitian dapat mengukur apa yang ingin diukur (Siregar 2015:75). Untuk mengetahui validitas bisa digunakan $\mathrm{DF}=\mathrm{N}-2$ dan probabilitas sebesar $5 \%$ atau 0,05 . Dasar pengambilan keputusannya adalah jika

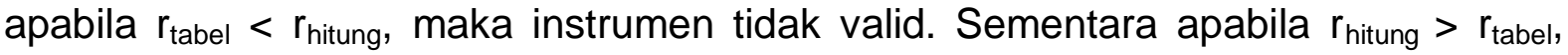
maka instrumen dikatakan valid. Pada penelitian ini, peneliti mengambil 20 sampel untuk dijadikan bahan validitas. $\mathrm{Df}=(20-2)=18$, maka tabel $\mathrm{r}$ pada angka 18 Product Moment adalah 0,468. Berikut adalah hasil uji validitas menggunakan SPSS untuk variabel $\mathrm{X}$ dan $\mathrm{Y}$ :

Tabel 1. Hasil Uji Validitas

\begin{tabular}{|l|r|r|r|r|r|}
\hline & $\begin{array}{r}\text { Scale Mean if } \\
\text { Item Deleted }\end{array}$ & $\begin{array}{r}\text { Scale Variance } \\
\text { if Item Deleted }\end{array}$ & $\begin{array}{c}\text { Corrected Item- } \\
\text { Total Correlation }\end{array}$ & $\begin{array}{c}\text { Squared } \\
\text { Multiple } \\
\text { Correlation }\end{array}$ & $\begin{array}{c}\text { Cronbach's } \\
\text { Alpha if Item } \\
\text { Deleted }\end{array}$ \\
\hline X1.1 & 38.45 & 94.366 & .617 & .738 & .897 \\
X1.2 & 38.90 & 93.884 & .671 & .739 & .895 \\
X1.3 & 38.65 & 98.450 & .479 & .751 & .901 \\
X1.4 & 39.20 & 95.747 & .475 & .719 & .904 \\
X1.5 & 39.00 & 91.579 & .673 & .881 & .894 \\
Y1.1 & 39.55 & 91.945 & .639 & .753 & .895 \\
Y1.2 & 38.60 & 98.779 & .468 & .687 & .907 \\
Y1.3 & 40.40 & 87.200 & .771 & .915 & .889 \\
Y1.4 & 40.80 & 87.011 & .708 & .747 & .892 \\
Y1.5 & 41.30 & 89.905 & .706 & .785 & .892 \\
Y1.6 & 41.10 & 94.305 & .572 & .824 & .898 \\
Y1.7 & 40.70 & 88.853 & .719 & .859 & .892 \\
Y1.8 & 40.00 & 86.842 & .588 & .659 & .899 \\
Y1.9 & 41.05 & 87.524 & .629 & .865 & .896 \\
\hline
\end{tabular}

Sumber: Data olahan SPSS Versi 24.0

Berdasarkan tabel di atas, seluruh item pertanyaan untuk variabel $X$ dan variabel $Y$ nilai koefisien $r_{\text {hitung }}>r_{\text {tabel, }}$, sehingga dapat dinyatakan bahwa semua item pertanyaan adalah valid dan dapat dijadikan sebagai instrumen penelitian. Hal ini dapat dilihat pada kolom Corrected Item-Total Correlation yang menunjukkan 
validitas butir pertanyaan yang lebih besar dari 0,468. Dengan demikian, instrumen penelitiannya valid, karena $r_{\text {hitung }}>r_{\text {tabel }}$.

\section{Uji Reliabilitas}

Reliabilitas dihitung dengan metode Cronbach's Alpha Based on Standardized Items yang pada penelitian ini sebesar 0,906>0,468. Hal ini berarti instrumen dinyatakan reliabel. Berikut adalah hasil pengujian Cronbach's Alpha Based On Standardized Items yang dianalisis dengan menggunakan SPSS:

\section{Tabel 2. Hasil Uji Reliabilitas Instrumen}

\begin{tabular}{|r|r|r|}
\hline $\begin{array}{c}\text { Cronbach's } \\
\text { Alpha }\end{array}$ & $\begin{array}{c}\text { Cronbach's } \\
\text { Alpha Based on } \\
\text { Standardized } \\
\text { Items }\end{array}$ & N of Items \\
\hline .903 & .906 & 14 \\
\hline
\end{tabular}

Sumber: Data olahan SPSS Versi 24.0

Berdasarkan di atas diketahui nilai Cronbach's Alpha Based on Standardized Items pada penilaian ini sebesar 0,906 > 0,468. Sehingga dapat dinyatakan bahwa semua instrumen penelitian ini adalah reliabel.

\section{Uji Normalitas}

Uji normalitas digunakan untuk mengetahui apakah populasi data distribusi normal atau tidak (Siregar, 2015: 153). Uji normalitas yang digunakan dalam penelitian ini adalah uji One sample Kolmogrov-Smirnov dengan menggunakan taraf signifikan lebih besar dari 0,05. Data dinyatakan berdistribusi normal jika signifikasi lebih besar dari $5 \%$ atau 0,05 .

Tabel 3. Hasil Uji Normalitas

\begin{tabular}{|l|l|r|r|}
\hline \multicolumn{2}{|l|}{} & \multicolumn{1}{|c|}{$\begin{array}{c}\text { Media } \\
\text { Sosial }\end{array}$} & $\begin{array}{c}\text { Partisipasi } \\
\text { Politik }\end{array}$ \\
\hline $\mathrm{N}$ & Mean & 20 & 20 \\
\hline $\begin{array}{l}\text { Normal } \\
\text { Parameters }\end{array}$ & Std. Deviation & 3.373 & 7.619 \\
\hline $\begin{array}{l}\text { Most Extreme } \\
\text { Differences }\end{array}$ & Absolute & .132 & .176 \\
\cline { 2 - 4 } & Positive & .107 & .176 \\
\cline { 2 - 4 } & Negative & -.132 & -.083 \\
\hline \multicolumn{2}{|l|}{ Kolmogorov-Smirnov Z } & .591 & .789 \\
\hline Asymp. Sig. (2-tailed) & .876 & .563 \\
\hline
\end{tabular}

Sumber: Data olahan SPSS Versi 24.0

Berdasarkan tabel One sample Kolmogrov-Smirnov diperoleh angka probabilitas atau Asymp. Sig. (2-tailed). Nilai ini dibandingkan dengan 0,05 atau menggunakan taraf signifikasi $5 \%$. Dengan pedoman pengambilan keputusan jika Asymp. Sig. (2-tailed) > 0,05 maka distribusi data normal dan jika Asymp. Sig. (2tailed) $<0,05$ maka distribusi data adalah tidak normal. Dilihat dari tabel 25 menunjukan bahwa distribusi data normal. Dengan demikian, proses pengolahan data dapat dilanjutkan ke tahap berikutnya yaitu analisis regresi linear sederhana. 
Jurnal Dinamika Pemerintahan

Vol.3, No. 1 (Januari 2020)

doi: $10.36341 /$ jdp.v3i1.1158

\section{HASIL DAN PEMBAHASAN}

\section{Deskripsi Responden}

Identitas responden dalam kegiatan penelitian merupakan suatu yang sangat penting untuk mengetahui umur, jenis kelamin, pendidikan, daerah asal, media sosial yang paling sering digunakan, waktu yang digunakan mengakses media sosial dan media yang digunakan untuk mengakses media sosial setiap individu yang dijadikan sampel. Untuk lebih jelasnya di bawah ini akan dideskripsikan secara jelas dari masing-masing karakteristik.

\section{Umur}

Secara keseluruhan jumlah responden dalam penelitian ini berdasarkan peringkat umur 17-22 (67\%), umur 23-28 (27\%) dan umur 29-34 (6\%). Maka dapat dilihat dari segi umur yang paling banyak mengisi kuesioner ini adalah responden yang berusia diantara 17-22 tahun sebesar $67 \%$, diurutan berikutnya adalah responden berusia diantara $23-28$ tahun sebesar $27 \%$ yang paling sedikit adalah responden berusia diantara 29-34 tahun sebesar 6\%. Dari segi umur responden, sebanyak 137 orang berumur diantara 17-22 tahun, 55 orang berumur diantara 23-28 tahun dan 12 orang berumur diantara 29-34 tahun.

Figur 1. Responden Berdasarkan Umur

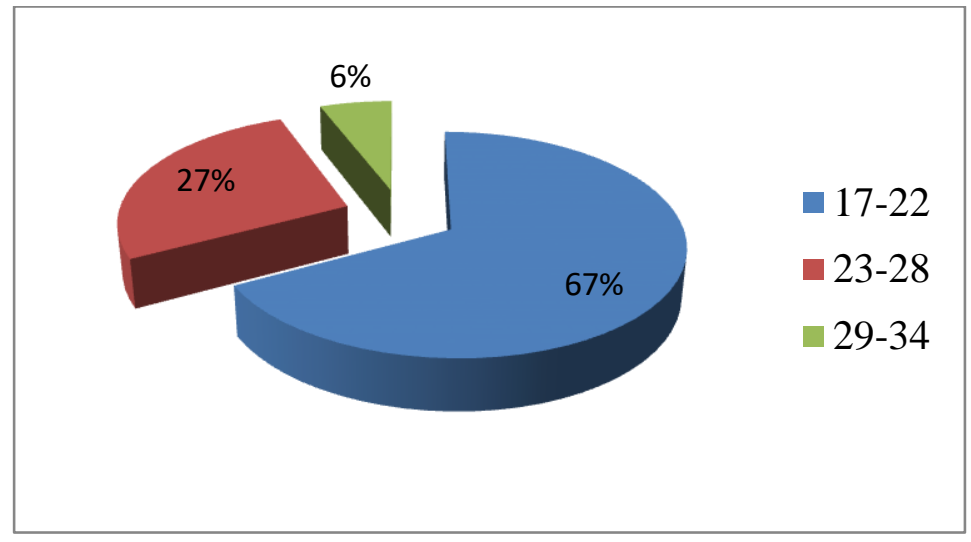

Sumber: Data olahan penulis

\section{Jenis Kelamin}

Berdasarkan hasil penelitian yang telah dilakukan peneliti, dengan teknik pengisian kuesioner yang telah diisi oleh responden. Berdasarkan jenis kelamin jumlah responden terbanyak adalah perempuan sebesar $64 \%$ dengan jumlah 130 orang dan diikuti jumlah responden terkecil adalah laki-laki sebesar 36\% dengan jumlah 74 orang. 
Figur 8. Jenis Kelamin

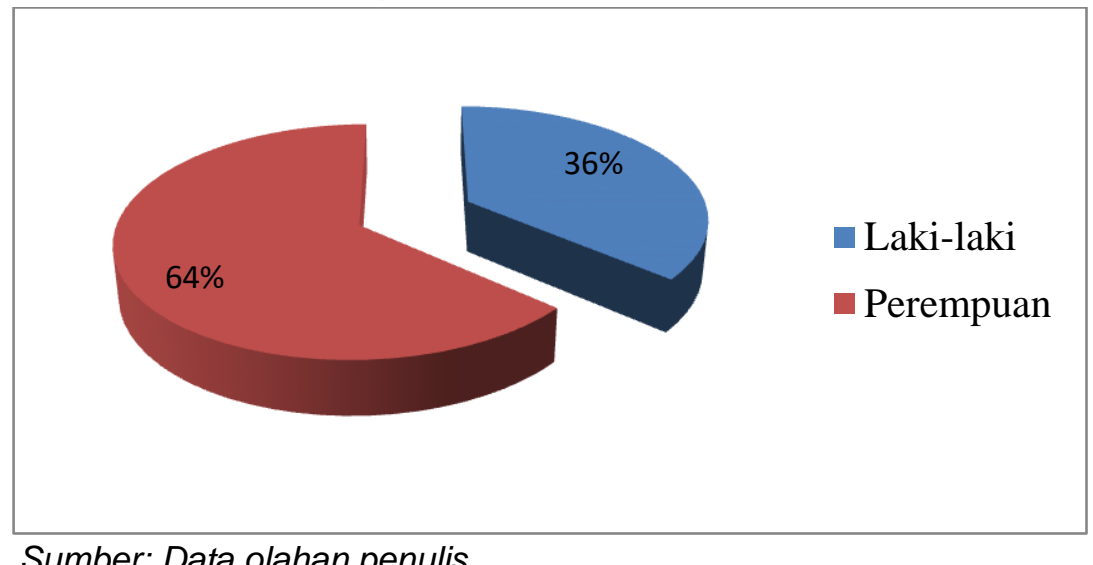

Sumber: Data olahan penulis

\section{Daerah Asal}

Selanjutnya pengguna media sosial milenial berdasarkan daerah asal yang paling banyak menggunakan media sosial adalah daerah asal Siak yaitu sebesar $47 \%$, Pekanbaru $15 \%$, Bengkalis $6 \%$, Meranti $7 \%$, Kampar $5 \%$, Pelalawan $4 \%$, Rokan Hilir 3\%, Indragiri Hulu 3\%, Indragiri Hilir 3\%, Kuantan Singingi 3\%, Dumai 2\% dan diikuti dengan daerah asal Rokan Hulu $2 \%$.

Figur 3. Daerah Asal Responden

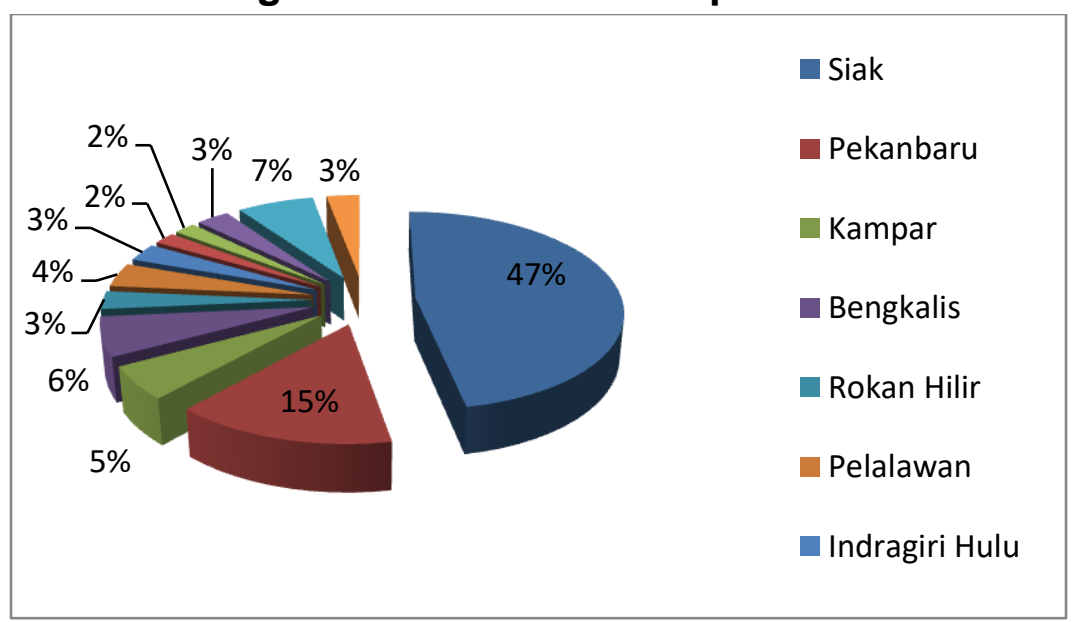

Sumber: Data olahan penulis

\section{Pendidikan}

Dari data yang diperoleh secara keseluruhan berdasarkan tingkat pendidikan responden, SMA $51 \%$, S1 44\%, S2 2\% dan lainnya 3\%. Dari segi tingkat pendidikan diketahui bahwa responden berdasarkan Media Sosial yang paling sering digunakan sebanyak 105 orang memiliki tingkat pendidikan SMA, 89 orang dengan tingkat pendidikan S1, 3 orang dengan tingkat pendidikan S2, dan 7 orang dengan memiliki pendidikan lainnya. 
Figur 4. Tingkat Pendidikan

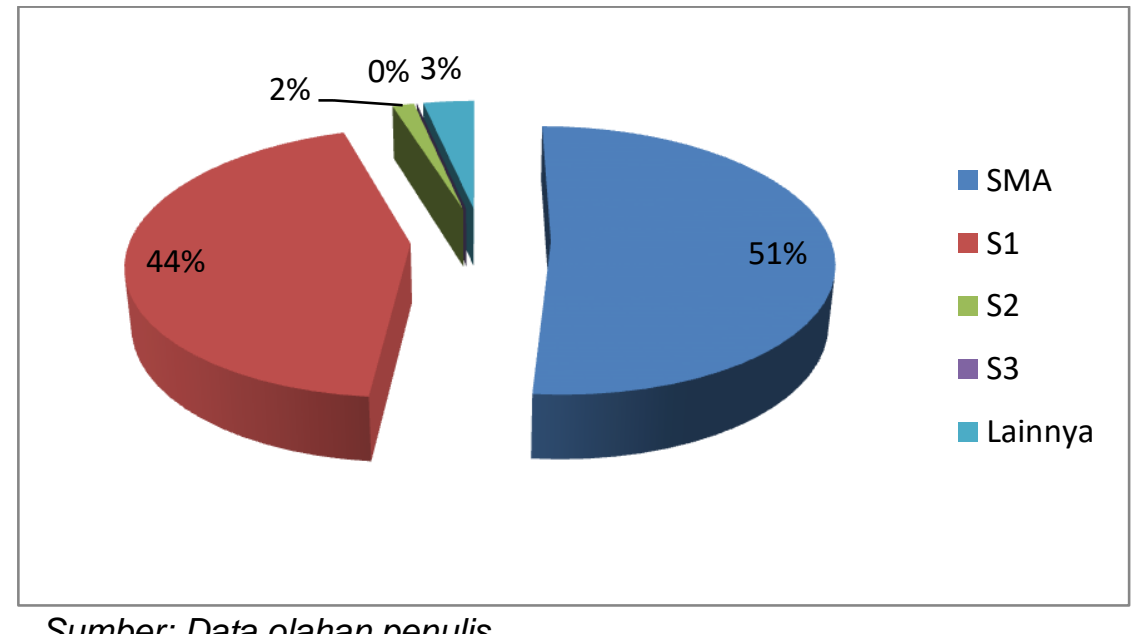

Sumber: Data olahan penulis

\section{Media sosial yang serimg digunakan}

Berdasarkan media sosial yang paling sering digunakan, dapat diketahui bahwa data dari keseluruhan responden adalah pengguna WhatsApp sebesar $(62.7 \%)$, Instagram sebesar (18.6\%) dan diikuti Facebook (16.2\%). Dari segi data responden diketahui 128 orang menggunakan media sosial WhatsApp, 38 orang menggunakan media sosial Instagram, 33 orang menggunakan media sosial Facebook, 3 orang menggunakan media sosial Youtube, 1 orang menggunakan media sosial Line dan 1 orang menggunakan media sosial lainnya.

Figur 5. Media Sosial yang paling sering digunakan

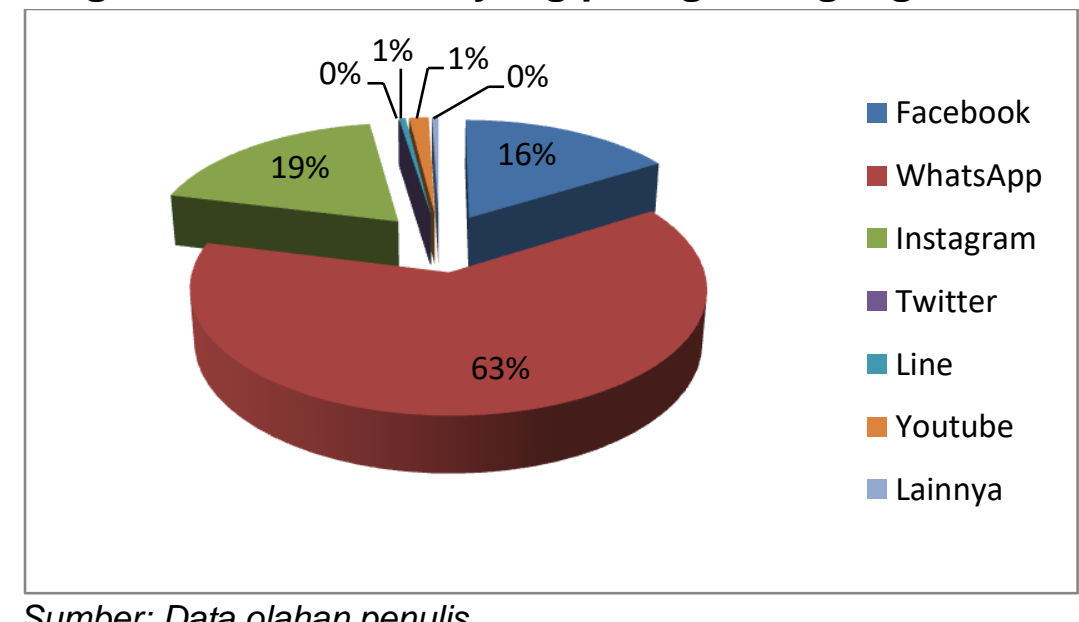

Sumber: Data olahan penulis

Waktu yang dipakai untuk mengakses media sosial/hari

Berdasarkan dari jumlah responden penelitian secara keseluruhan, jumlah responden berdasarkan waktu yang dipakai untuk mengakses media sosial/hari yang paling banyak yaitu $>5$ jam sebesar (28.4\%), 3 jam sebesar $(25 \%), 2$ jam sebesar (21.1\%), 4 jam (13.7\%) dan diikuti dengan yang paling sedikit yaitu 1 jam sebesar (11.8\%). 
Figur 6. Waktu yang dipakai untuk mengakses media sosial/hari

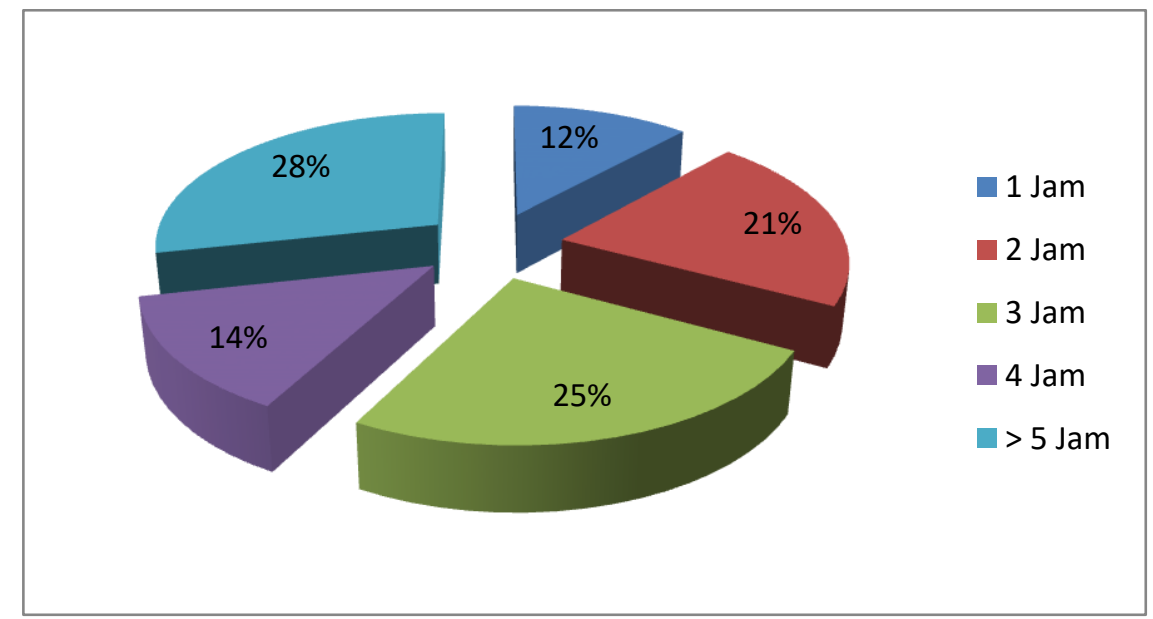

Sumber: Data olahan penulis

\section{Media yang digunakan untuk mengakses media sosial}

Berdasarkan media yang digunakan untuk mengakses media sosial, responden lebih banyak mengakses menggunakan Smartphone sebesar 98\% dibandingkan mengakses dengan Tablet, PC/Desktop, laptop dan yang lainnya. Dilihat hari segi media yang sering digunakan, 200 orang lebih banyak menggunakan smartphone, 2 orang menggunakan tablet dan 2 orang menggunakan media lainnya.

Figur 7. Media yang digunakan untuk mengakses media sosial

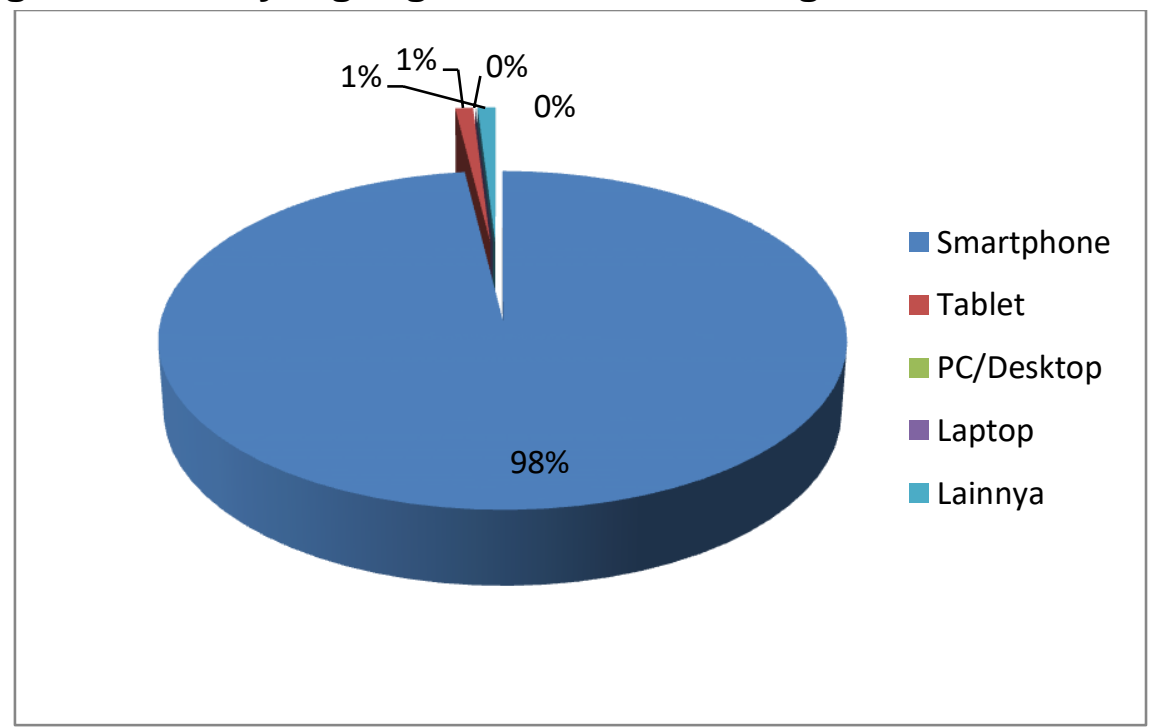

Sumber: Data olahan penulis 


\section{Deskripsi Tanggapan Responden}

Peneliti dalam hal ini akan menjelaskan deskripsi jawaban responden sebagai berikut:

Figur 8: Media sosial memberikan banyak informasi tentang masalah politik, sosial, ekonomi, budaya dan informasi politik lainnya

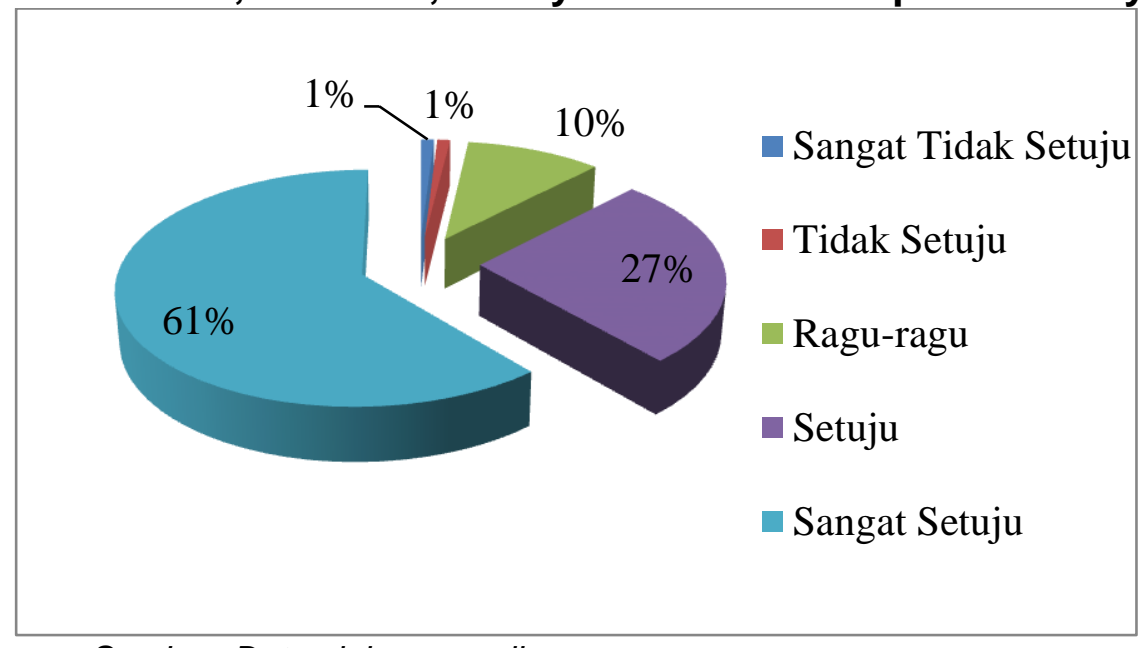

Sumber: Data olahan penulis

Berdasarkan jawaban di atas dapat dilihat bahwa responden lebih dominan menjawab sangat setuju tentang media sosial memberikan banyak informasi tentang masalah politik, sosial, ekonomi, budaya dan informasi politik lainnya, yaitu berjumlah 125 orang atau sebesar $61 \%$, diikuti dengan setuju berjumlah 54 orang atau sebesar $27 \%$, ragu-ragu berjumlah 21 orang atau sebesar $10 \%$, tidak setuju berjumlah 2 orang atau sebesar $1 \%$, dan sangat tidak setuju berjumlah 2 orang atau sebesar $1 \%$.

Figur 9: Media sosial menjadi ruang publik dalam diskusi

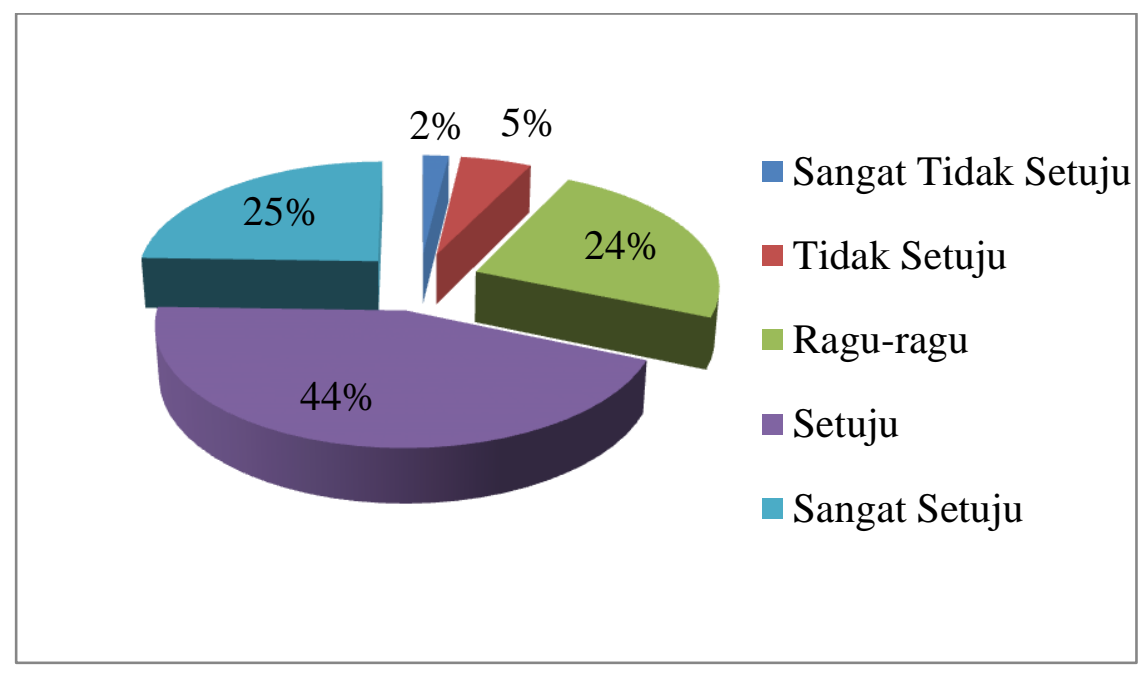

Sumber: Sumber: Data olahan penulis

Berdasarkan jawaban di atas dapat dilihat bahwa responden lebih dominan menjawab setuju tentang media sosial menjadi ruang bagi publik dalam mendiskusikan isu-isu terkini, yaitu berjumlah 90 orang atau sebesar $44 \%$, diikuti 
dengan sangat setuju berjumlah 50 orang atau sebesar $25 \%$, ragu-ragu berjumlah 49 orang atau sebesar $24 \%$, tidak setuju berjumlah 11 orang atau sebesar $5 \%$, dan sangat tidak setuju berjumlah 4 orang atau sebesar $2 \%$.

Figur 10: Media sosial menjadi sarana yang efektif dalam membangun dan melestarikan budaya

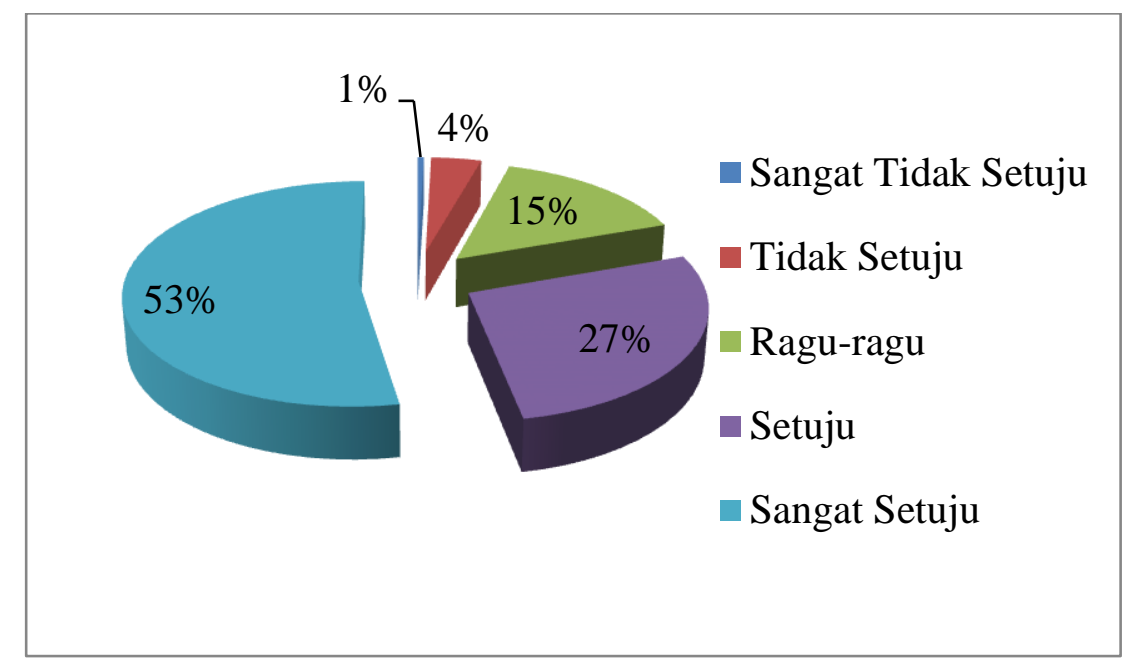

Sumber: Sumber: Data olahan penulis

Berdasarkan jawaban di atas dapat dilihat bahwa responden lebih dominan menjawab sangat setuju tentang media sosial menjadi sarana yang efektif dalam membangun dan melestarikan budaya, yaitu berjumalah 108 orang atau sebesar $53 \%$, diikuti degan setuju berjumlah 56 orang atau sebesar $27 \%$, ragu-ragu berjumlah 31 orang aau sebesar $15 \%$, tidak setuju berjumlah 8 orang atau sebesar $4 \%$, dan sangat tidak setuju berjumlah 1 orang atau sebesar $1 \%$.

Figur 11: Konten hiburan di media sosial dapat meredakan ketegangan di Masyarakat

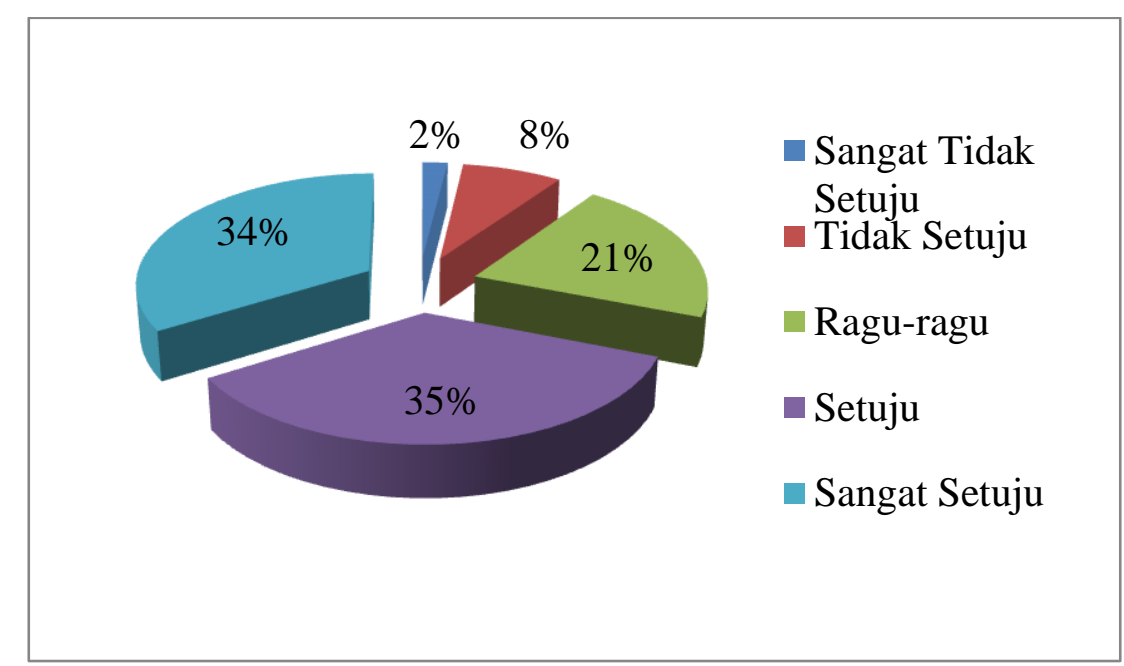

Sumber: Sumber: Data olahan penulis

Berdasarkan jawaban di atas dapat dilihat bahwa responden lebih dominan menjawab setuju tentang berbagai hiburan yang ada di media sosial dapat digunakan untuk meredakan ketegangan sosial, yaitu berjumlah 72 orang atau 
sebesar $35 \%$, diikuti dengan sangat setuju berjumlah 69 orang atau sebesar $34 \%$, ragu-ragu berjumlah 43 orang atau sebesar $21 \%$, tidak setuju berjumlah 16 orang atau sebesar $8 \%$, dan sangat tidak setuju 4 orang atau sebesar $2 \%$.

\section{Figur 12: Media sosial berguna sebagai sarana mobilisasi opini publik}

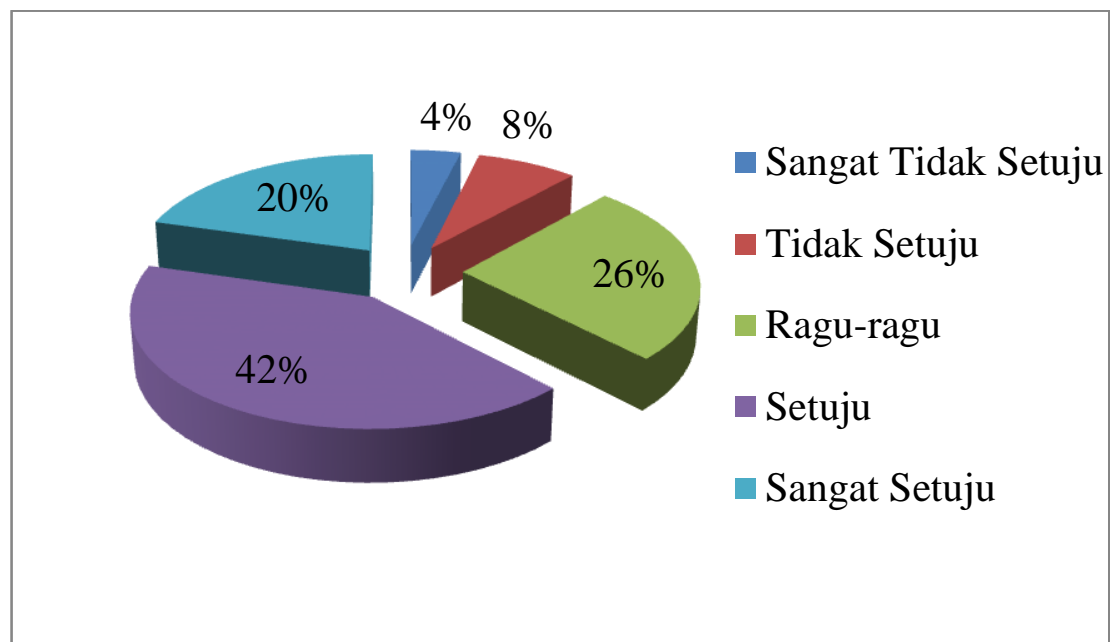

Sumber: Sumber: Data olahan penulis

Berdasarkan jawaban di atas dapat dilihat bahwa responden lebih dominan menjawab setuju tentang media sosial berguna sebagai sarana mobilisasi opini publik terkait sebuah isu, yaitu berjumlah 85 orang atau sebanyak $42 \%$, diikuti dengan ragu-ragu berjumlah 53 orang atau sebesar $26 \%$, sangat setuju berjumlah 42 orang atau sebesar $20 \%$, tidak setuju berjumlah 16 orang atau sebesar $8 \%$, dan sangat tidak setuju berjumlah 8 orang atau sebesar $4 \%$.

Figur 13: Menyampaikan kritik kepada pemerintah melalui media sosial

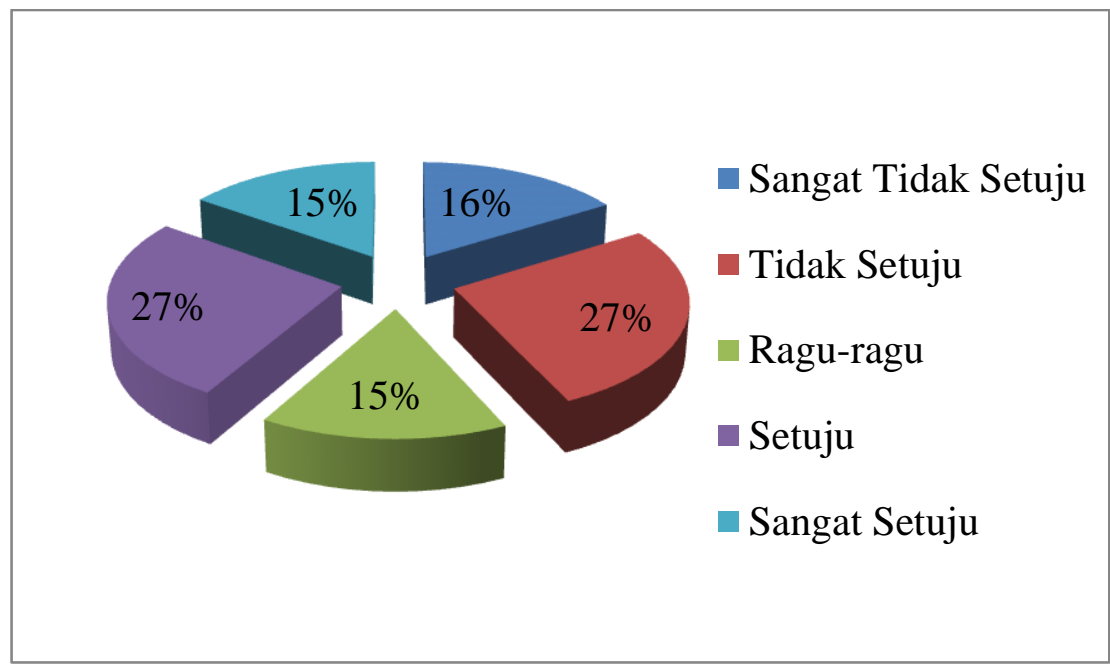

Sumber: Sumber: Data olahan penulis

Berdasarkan jawaban di atas dapat dilihat bahwa responden lebih dominan menjawab tidak setuju dan setuju. Ini dapat diketahui bahwa ada yang setuju dan tidak setuju tentang saya menyampaikan kritik kepada pemerintah terkait sebuah kebijakan dengan menggunakan media sosial, yaitu tidak setuju berjumlah 55 orang atau sebanyak $27 \%$ dikuti tidak setuju berjumlah 54 orang atau sebanyak $27 \%$, 
sangat tidak setuju berjumlah 33 orang atau sebesar $16 \%$, sangat setuju berjumlah 31 orang atau sebesar $15 \%$, dan ragu-ragu berjumlah 31 orang atau sebesar $15 \%$.

\section{Figur 14: Selalu menggunakan hak pilih pada setiap pemilu}

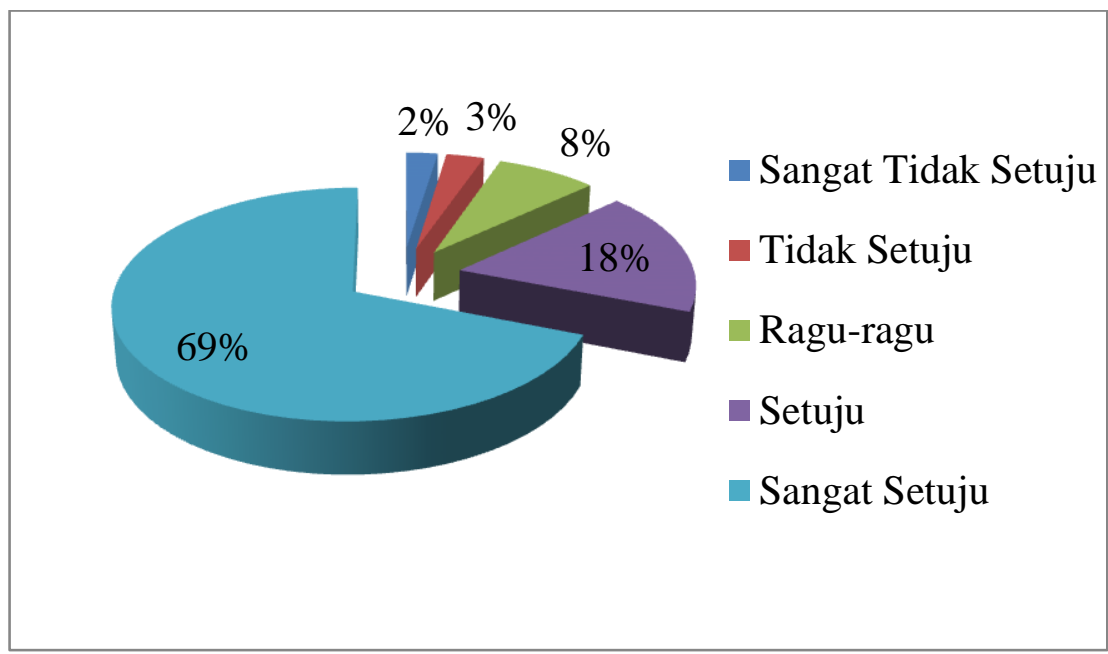

Sumber: Sumber: Data olahan penulis

Berdasarkan jawaban di atas dapat dilihat bahwa responden lebih dominan menjawab sangat setuju tentang saya selalu menggunakan hak pilih pada setiap pemilu (pilkada, pileg, pilpres), yaitu berjumlah 141 orang atau sebanyak $69 \%$, diikuti dengan setuju berjumlah 36 orang atau sebesar $18 \%$, ragu-ragu berjumlah 16 orang atau sebesar $8 \%$, tidak setuju berjumlah 6 orang atau sebesar $3 \%$, dan sangat tidak setuju berjumlah 5 orang atau sebesar $2 \%$.

\section{Figur 15: Terlibat aktif dalam diskusi politik di media sosial}

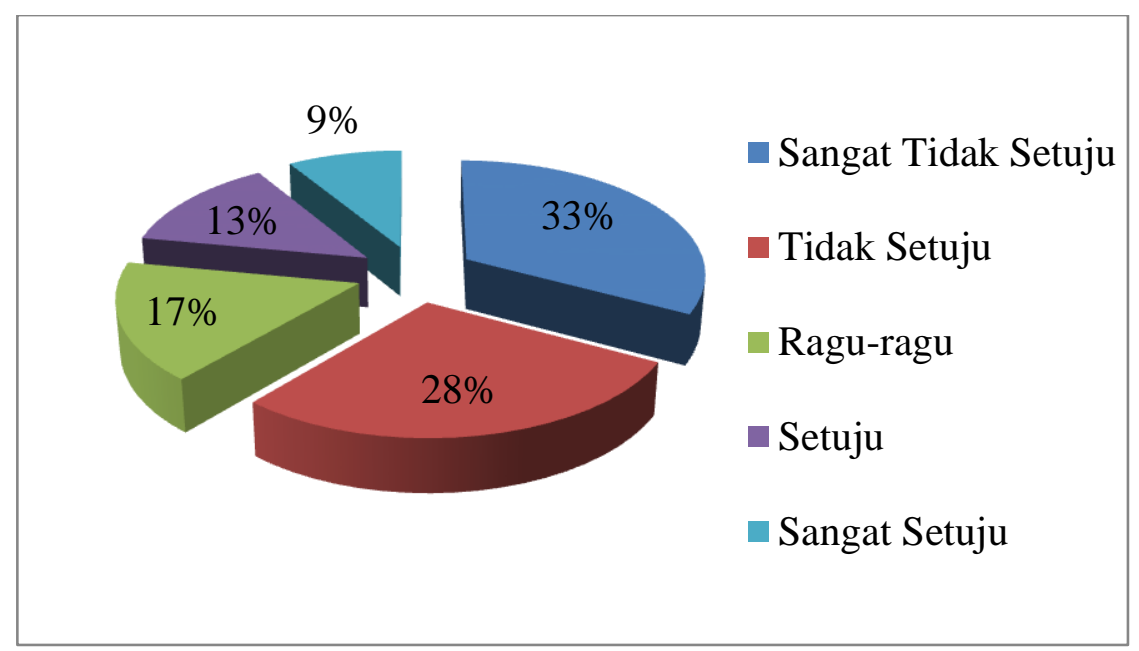

Sumber: Sumber: Data olahan penulis

Berdasarkan jawaban di atas dapat dilihat bahwa responden lebih dominan menjawab sangat tidak setuju tentang saya terlibat secara aktif dalam diskusi terkait situasi politik di media sosial dan forum-forum diskusi lainnya, yaitu berjumlah 67 orang atau sebanyak $33 \%$, diikuti dengan tidak setuju berjumlah 58 orang atau sebesar $28 \%$, ragu-ragu berjumlah 43 orang atau sebesar $17 \%$, setuju berjumlah 27 orang atau sebesar $13 \%$, dan sangat setuju berjumlah 18 orang atau sebesar $9 \%$. 


\section{Figur 16: Ikut berkampanye/mempromosikan calon tertentu di media sosial dan forum pertemuan lainnya}

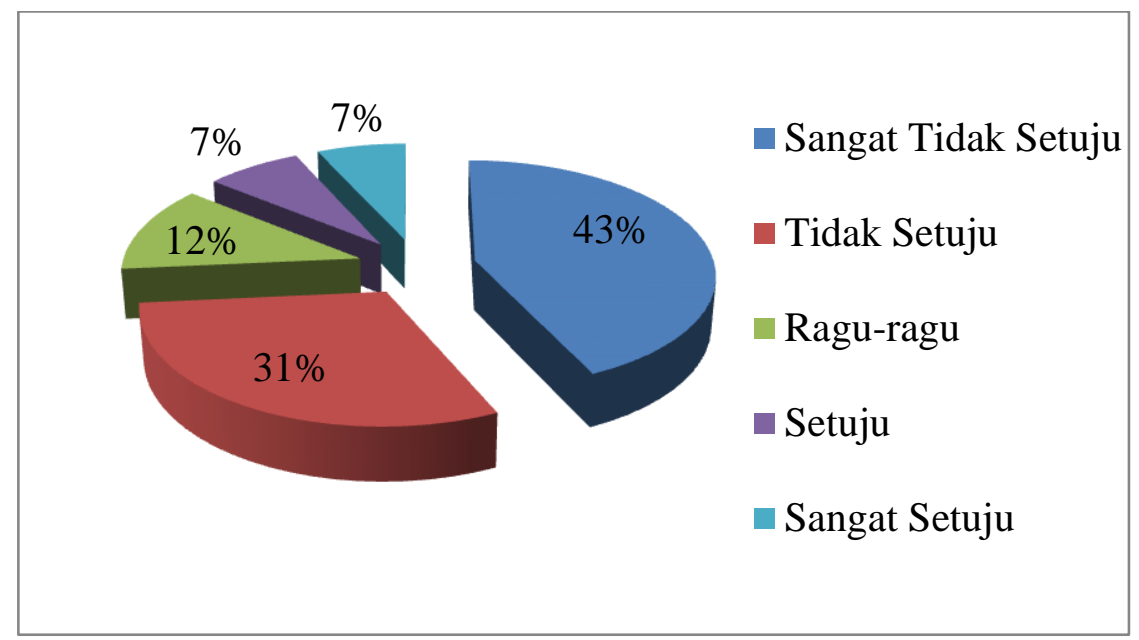

Sumber: Data olahan penulis

Berdasarkan jawaban di atas dapat dilihat bahwa responden lebih dominan menjawab sangat tidak setuju tentang saya ikut berkampanye/mempromosikan calon tertentu di media sosial dan berbagai forum pertemuan lainnya, yaitu berjumlah 88 orang atau sebanyak $43 \%$, diikuti dengan tidak setuju berjumlah 62 orang atau sebesar $31 \%$, ragu-ragu berjumlah 25 orang atau sebesar $12 \%$, setuju berjumlah 15 orang atau sebesar $7 \%$, dan sangat setuju berjumlah 14 orang atau sebesar $7 \%$.

Figur 17: Menjadi kader partai politik

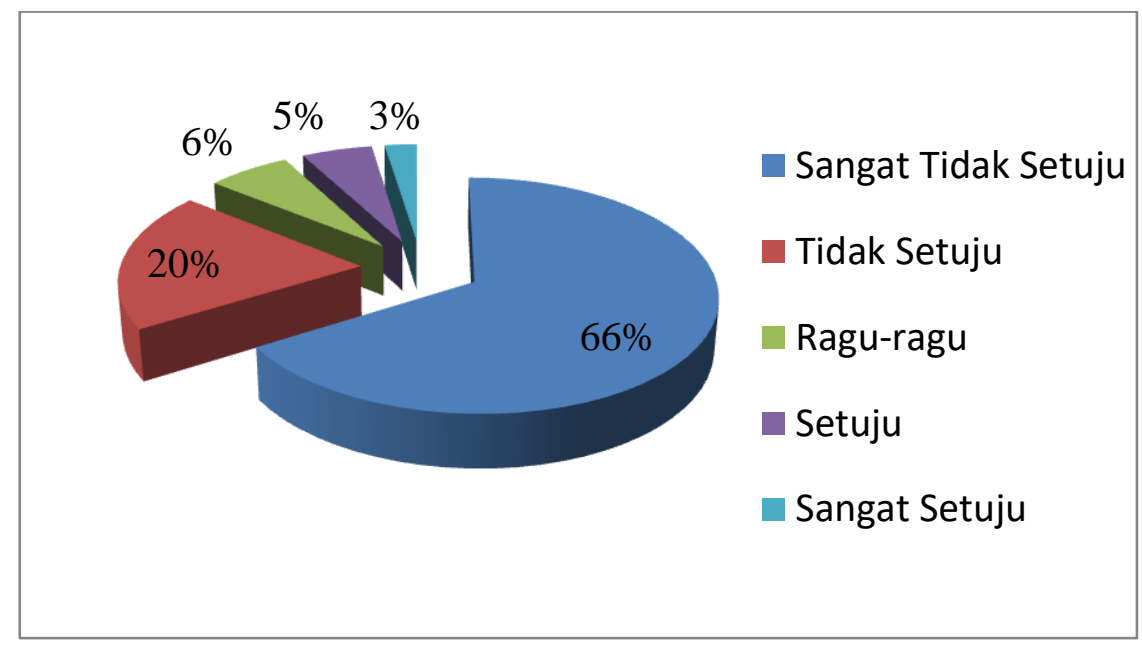

Sumber: Data olahan penulis

Berdasarkan jawaban di atas dapat dilihat bahwa responden lebih dominan menjawab sangat tidak setuju tentang saya terlibat menjadi kader partai politik, yaitu berjumlah 135 otang atau sebanyak $66 \%$, diikuti dengan tidak setuju 40 orang atau sebesar $20 \%$, ragu-ragu berjumlah 13 orang atau sebesar $6 \%$, setuju berjumlah 11 otang atau sebesar $5 \%$, dan sangat setuju berjumlah 5 orang atau sebesar $3 \%$. 
Figur 18: Kedekatan emosional terhadap partai politik

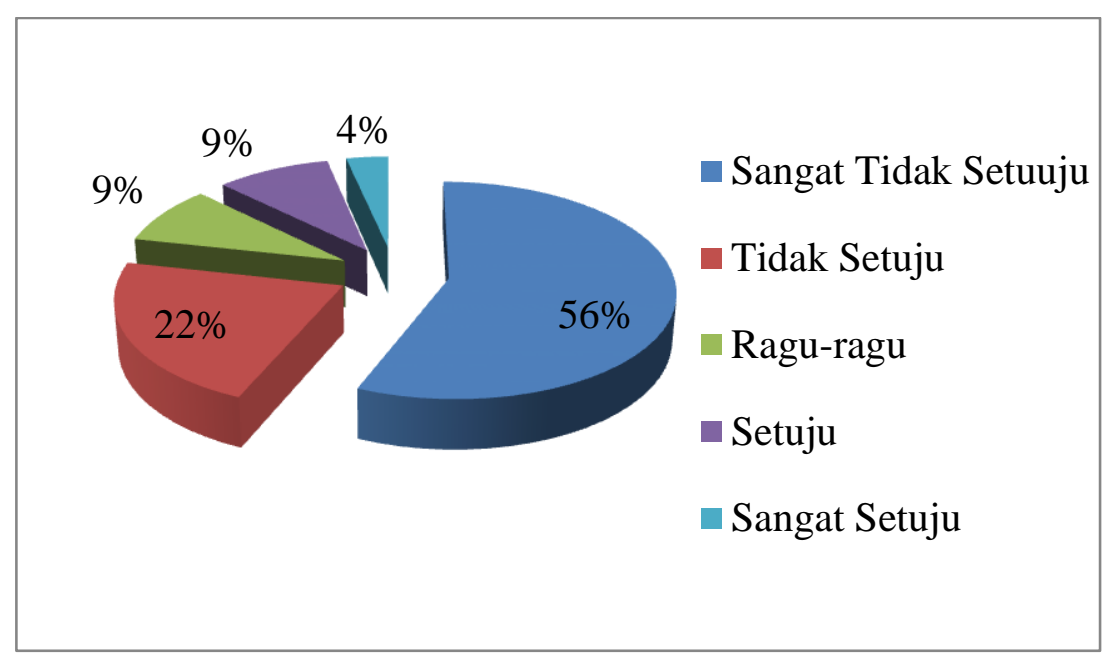

Sumber: Data olahan penulis

Berdasarkan jawaban di atas dapat dilihat bahwa responden lebih dominan menjawab sangat tidak setuju tentang saya memiliki kedekatan emosional terhadap salah satu partai politik, yaitu berjumlah 115 orang atau sebesar $56 \%$, diikuti dengan tidak setuju berjumlah 45 orang atau sebesar $22 \%$, setuju berjumlah 19 orang atau sebesar $9 \%$, ragu-ragu berjumlah 18 orang atau sebesar $9 \%$, dan sangat setuju berjumlah 7 orang atau sebesar $4 \%$.

\section{Figur 19: Menyampaikan aspirasi publik melalui media sosial}

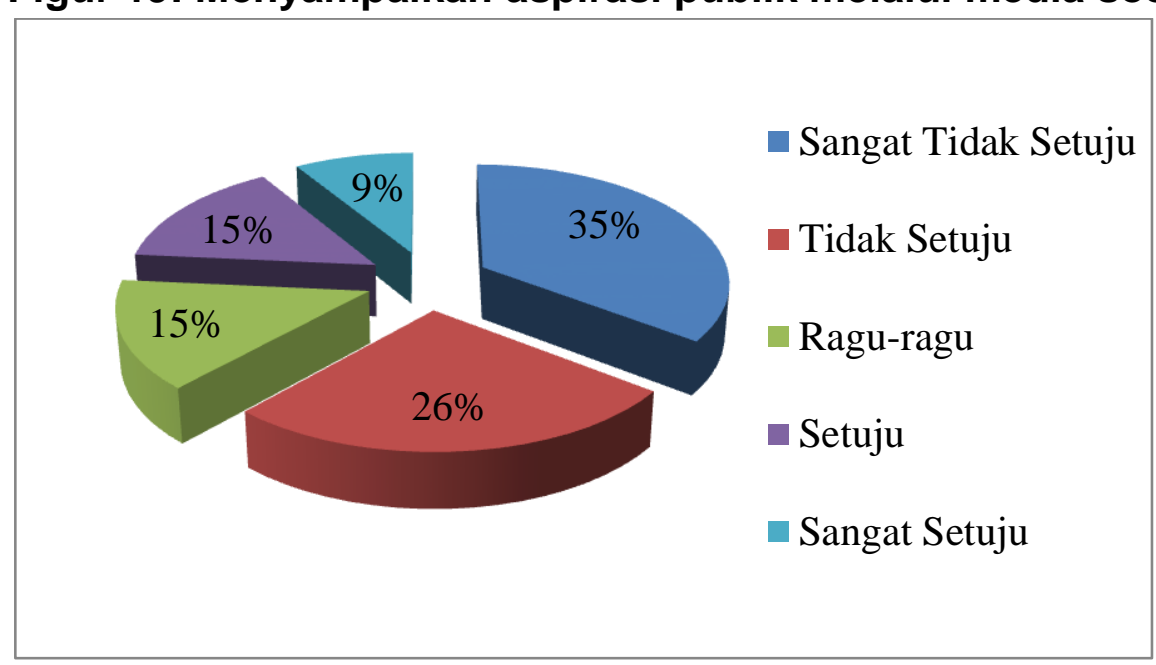

Sumber: Data olahan penulis

Berdasarkan jawaban di atas dapat dilihat bahwa responden lebih dominan menjawab sangat tidak setuju tentang saya menyampaikan aspirasi publik kepada pejabat dengan menggunakan media sosial dan saluran lainnya, yaitu berjumlah 72 orang atau sebesar $35 \%$, diikuti dengan tidak setuju 54 orang atau sebesar $26 \%$, ragu-ragu berjumlah 30 orang atau sebesar $15 \%$, setuju berjumlah 30 orang atau sebesar $15 \%$, dan sangat setuju berjumlah 18 orang atau sebesar $9 \%$. 
Figur 20: Berpartisipasi dalam kegiatan demonstrasi kebijakan pemerintah yang tidak berpihak kepada rakyat

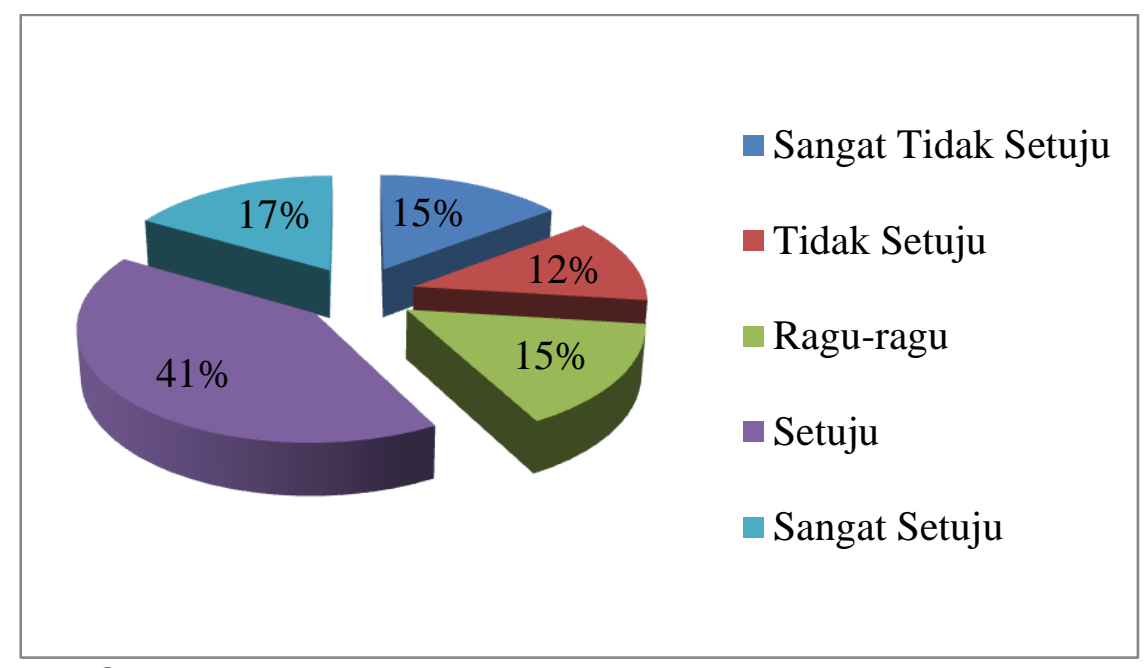

Sumber: Data olahan penulis

Berdasarkan jawaban di atas dapat dilihat bahwa responden lebih dominan menjawab setuju tentang saya turut berpartisipasi dalam kegiatan demonstrasi terhadap suatu kebijakan pemerintah yang tidak berpihak kepada rakyat, yaitu berjumlah 84 otang atau sebesar $41 \%$, diikuti dengan sangat setuju berjumlah 34 orang atau sebesar $17 \%$, ragu-ragu berjumlah 31 orang atau sebesar $15 \%$, sangat tidak setuju berjumlah 30 orang atau sebesar $15 \%$, dan tidak setuju berjumlah 25 orang atau sebesar $12 \%$.

Figur 21: Tindakan kekerasan merupakan hal yang wajar dalam menyampaikan aspirasi publik

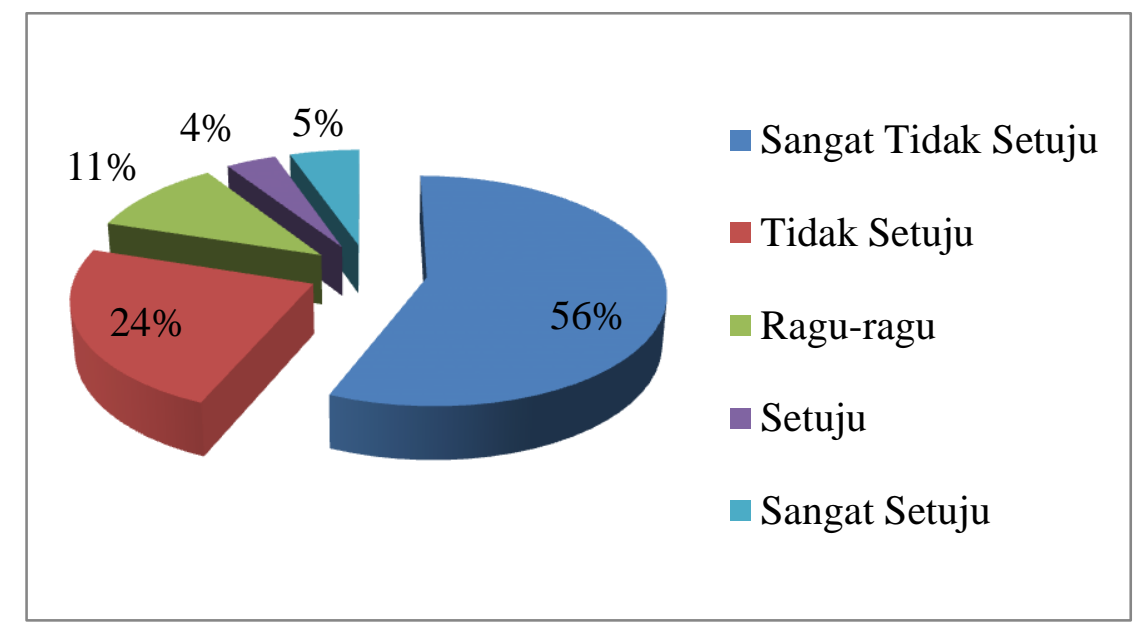

Sumber: Data olahan penulis

Berdasarkan jawaban di atas dapat dilihat bahwa responden lebih dominan menjawab sangat tidak setuju tentang tindakan kekerasan merupakan hal yang wajar dilakukan dalam menyampaikan aspirasi publik, yaitu berjumlah 115 orang atau sebesar $56 \%$, diikuti dengan tidak setuju berjumlah 48 orang atau sebesar $24 \%$, ragu-ragu berjumlah 22 orang atau sebesar $11 \%$, sangat setuju berjumlah 11 orang atau sebesar $5 \%$, dan setuju berjumlah 8 orang atau sebesar $4 \%$. 
Jurnal Dinamika Pemerintahan

Vol.3, No. 1 (Januari 2020)

doi: $10.36341 /$ jdp.v3i1.1158

\section{Regresi Linear Sederhana}

Analisis regresi linear sederhana merupakan analisis data untuk melihat apakah ada pengaruh variabel $X$ terhadap variabel $Y$. Hasil perhitungan analisis regresi linear sederhana melalui SPSS, maka diperoleh nilai-nilai untuk variabel bebas dan variabel terikat dapat dilihat pada tabel berikut:

Tabel 4: Analisis Regresi Sederhana

\begin{tabular}{|c|c|c|c|c|c|c|}
\hline \multirow{2}{*}{\multicolumn{2}{|c|}{ Model }} & \multicolumn{2}{|c|}{ Unstandardized Coefficients } & \multirow{2}{*}{$\begin{array}{c}\text { Standardized } \\
\text { Coefficients } \\
\text { Beta }\end{array}$} & \multirow[b]{2}{*}{$\mathrm{T}$} & \multirow[b]{2}{*}{ Sig. } \\
\hline & & B & Std. Error & & & \\
\hline \multirow[t]{2}{*}{1} & (Constant) & 13.398 & 3.175 & & 4.220 & .000 \\
\hline & TOTALX & .463 & .156 & .205 & 2.973 & .003 \\
\hline
\end{tabular}

Sumber: Data olahan SPSS Versi 24,0

Adapun proses pengambilan keputusan regresi linear sederhana dapat dilakukan juga dengan membandingkan signifikansi (sig) dengan 0,05 hasil output SPSS adalah (1) jika nilai signifikansi (sig) lebih kecil < dari probabilitas 0,05 mengandung arti bahwa ada pengaruh media sosial $(X)$ terhadap partisipasi politik (Y); (2) jika nilai signifikansi (sig) lebih besar > dari probabilitas 0,05 mengandung arti bahwa tidak ada pengaruh media sosial $(\mathrm{X})$ terhadap partisipasi politik $(\mathrm{Y})$. Berdasarkan tabel di atas, maka dapat disusun persamaan regresi sederhana sebagai berikut:

$$
\begin{aligned}
& Y=a+b X \\
& Y=13.398+0,463 X
\end{aligned}
$$

Makna dari angka-angka dalam persamaan regresi diatas adalah nilai a (konstanta) $=13.398$, menunjukkan bahwa apabila nilai variabel $X=0$, maka nilai variabel $Y$ sebesar 13.398. Nilai $b$ (koefisien regresi) $=0,463$, menunjukkan bahwa apabila nilai variabel $X$ meningkat dengan satu-satuan, maka variabel $Y$ akan mengalami peningkatan sebesar 0,463 satuan dengan asumsi variabel $X$ tetap atau konsisten. Maka dapat dikatakan koefisien bernilai positif antara variabel $X$ dengan variabel $Y$, setiap peningkatan variabel $X$ sebesar 1 satuan akan meningkatkan variabel $\mathrm{Y}$. 
Figur 22: Scatter-Plot

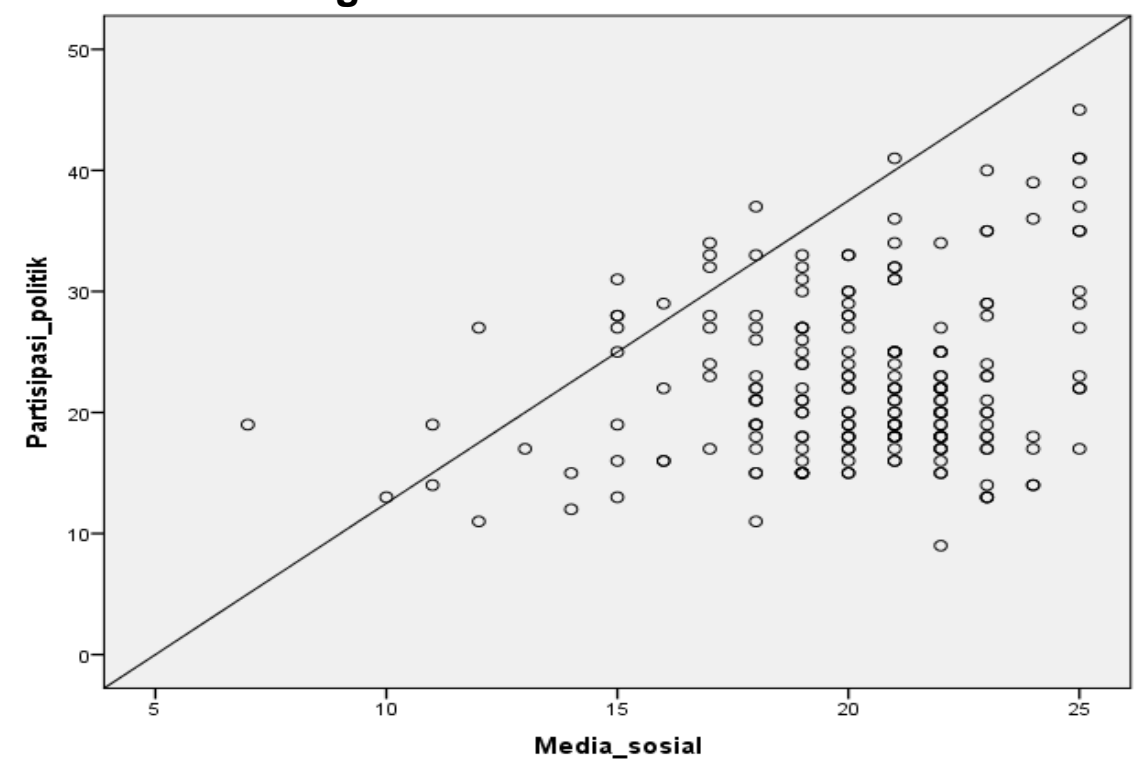

Sumber: Data olahan SPSS Versi 24,0

Pada figur di atas menunjukkan area penerimaan hipotesis yang diajukan penulis yaitu ada pengaruh media sosial terhadap partisipasi politik milenial di Riau. Posisi Scater Plot menunjukan adanya hubungan positif antara media sosial dengan partisipasi politik milenial, namun nilainya rendah hanya sebesar 0,205.

\section{KESIMPULAN}

Berdasarkan analisis hasil penelitian dan pembahasan yang telah diuraikan pada bab sebelumnya, maka penelitian mengenai pengaruh media sosial terhadap tingkat patisipasi politik milenial di provinsi Riau dapat ditarik kesimpulan bahwa media sosial merupakan alat saluran komunikasi dalam menyampaikan informasi kepada khalayak. Hal ini dapat digambarkan melalui uji hipotesis yang menunjukkan adanya pengaruh antara media sosial terhadap partisipasi politik milenial di Riau meskipun nilainya rendah yaitu sebesar 0,205 (20,5\%). Sehingga hipotesis terbukti bahwa Ho ditolak dan Ha diterima. Hal ini juga menunjukkan bahwa ada variabel-variabel lain yang turut mempengaruhi partisipasi politik milenial di Riau. Hal ini juga merupakan keterbatasan dari penelitian ini yang hanya fokus untuk mengungkap pengaruh media sosial terhadap partisipasi politik milenial di Riau, namun tidak turut melibatkan variabel-variabel lain sebagai objek penelitian. Penulis mengajukan beberapa saran yaitu (1) partai politik sebaiknya menjadikan generasi milenial sebagai fokus program kaderisasi partai; (2) generasi milenial sebaiknya tidak hanya fokus dalam memberikan hak pilih dalam pemilu sebagai satu-satunya indikator partisipasi politik, tetapi juga memberikan kritik secara aktif kepada kebijakankebijakan pemerintah yang tidak pro-rakyat.

\section{REFERENSI}

Al Walidah, Iffah. 2017. "Tabayyun Di Era Generasi Millenial." Jurnal Living Hadis 2(2): 317-44.

Ainiyah, Nur. 2018. "Remaja Millenial Dan Media Sosial: Media Sosial Sebagai 
Media Informasi Pendidikan Bagi Remaja Millenial." JPII 2(2): 221-36. www.ojs.pps-ibrahimy.ac.id > index.php > jpii > article > download.

Arikunto, Suharsimi. 2006. Metode Penelitian Kuantitatif. Jakarta: Bumi A ksara.

BPS. 2016. Tabel Penduduk Menurut Kelompok Umur Dan Jenis Kelamin. Pekanbaru. https://riau.bps.go.id/statictable/2016/01/25/209/pendudukprovinsi-riau-menurut-kelompok-umur-dan-jenis-kelamin-2014.html.

Budiardjo, Miriam. 2008. Dasar-dasar IImu Politik, PT Gramedia Pustaka Utama. Jakarta

Budiardjo, Miriam. 2009. Partisipasi dan Partai Politik, PT Gramedia Pustaka Utama,.Jakarta

Bisri, A. Zaini. "Partisipasi Politik Dalam Keterbukaan Informasi Publik Studi Kasus Interaksi Pattiro Dengan Pemerintah Kota Semarang." ejournal.undip.ac.id > index.php > politika > article > download\%0A.

Cahyono, Anang Sugeng. 2016. "Pengaruh Media Sosial Terhadap Perubahan Sosial Masyarakat Di Indonesia." Jurnal Publiciana 9(1): 140-57.

Cholisin. 2007. Dasar-dasar IImu Politik. Yogyakarta: UNY Press.

Dollarhide, Maya E. 2019. "Social Media Definition." Investopedia. https://www.investopedia.com/terms/s/social-media.asp.

Hidayat, Ahmad Nur. 2018. "Beda Cara Generasi Milenial Dalam Politik." Kompas.com. https://nasional.kompas.com/read/2018/09/17/19090001/bedacara-generasi-milenial-dalam-politik?page=all.

Kaplan, Andreas M., and Michael Haenlein. 2010. "Users of the World, Unite! The Challenges and Opportunities of Social Media." Business Horizons 53: 59-68.

Mas'oed, Mohtar, dan Mac Andrew Colin. 2011. Perbandingan Sistem Politik, Gadjah Mada University Press. Yogyakarta

McQuail, Denis. 2011. Teori Komunikasi Massa, Salemba Humanika. Jakarta

Muhaling, Arther. 2015. "Partisipasi Politik Masyarakat Dalam Pemilukada Di Kecamatan Siau Barat Selatan Kabupaten Sitaro." Politico: Jurnal IImu Politik $1(5)$.

Muslimin, Khoirul. 2019. Buku Ajar Komunikasi Politik. Yogyakarta: UNISNU Press.

Putra, Yanuar Surya. 2016. "Theoritical Review: Teori Perbedaan Generasi." Among Makarti https://jurnal.stieama.ac.id/index.php/ama/article/viewFile/142/133.

Rumyeni, Rumyeni. "PENERIMAAN MEDIA SOSIAL DI KALANGAN MAHASISWA KOTA PEKANBARU." Jurnal IImu Komunikasi 8(2): 117-32.

Siregar, Syofian. 2015. Statistik Parametrik Untuk Penelitian Kuantitatif: Dilengkapi Dengan Perhitungan Manual Dan Aplikasi SPSS Versi 17. Jakarta: Bumi Aksara.

Winarno, Sugeng. 2018. "Partisipasi Politik Milenial." Harian Bhirawa. http://research-report.umm.ac.id/index.php/API-BAA/article/view/2188. 